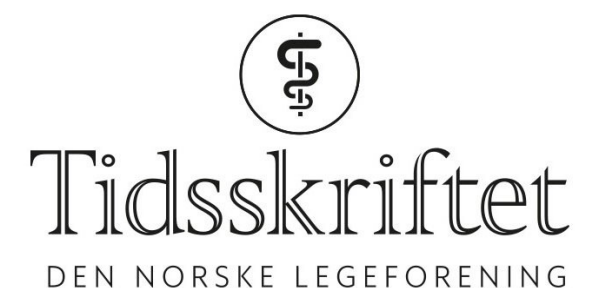

DEN NORSKE LEGEFORENING

\title{
Storebror ser antibiotikabruken min!
}

DEBATT

\section{JON HENRIK LAAKE}

E-post: jlaake@ous-hf.no

Jon Henrik Laake (f. 1963) er dr.med., spesialist i thoraxanestesiologi og i intensivmedisin og overlege ved Akuttklinikken, Oslo universitetssykehus, Rikshospitalet.

Forfatter har fylt ut ICMJE-skjemaet og oppgir ingen interessekonflikter.

Helse Sør-Øst har innført et eget verktøy i pasientkurven for antibiotikaovervåkning. I prosessen før innføringen har ikke vi som skal bruke verktøyet, blitt hørt. Resultatet er et system som vil generere en rekke data som trolig ikke kan brukes til noen ting.

Regjeringen lanserte i 2015 en nasjonal strategi mot antibiotikaresistens (1). Mindre og riktigere bruk av antibiotika er en av målsettingene. I tiltakspakken angis det at regjeringen vil «innføre krav om diagnosekode på alle antibiotikaresepter til mennesker» og at den «vurderer å utvide Reseptregisteret, opprette en nasjonal laboratoriedatabase, utvikle et bedre tilpasset regelverk og på den måten sørge for nærmere sanntidstilgang til data» (1).

På regionalt nivå har Helse $\lceil\emptyset r-\emptyset$ st nå gjort antibiotikaovervåkning til en del av det «elektroniske kurveprosjektet». Flere av sykehusene i regionen benytter kurveprogrammet Metavision til observasjon og ordinering av legemidler, spesielt i regionens intensivenheter. I Oslo universitetssykehus ble programvaren tatt i bruk i min avdeling allerede i 2006. Helt siden den gang er vi flere som har etterspurt anledning til å høste data fra det som i realiteten er en gigantisk database. Til tross for gjentatte henvendelser til foretaksledelsen er dette ønsket ikke blitt imøtekommet. Dette har fratatt oss muligheten til å gjennomføre god intern kvalitetskontroll samt effektivt å utnytte data til forskningsformål. Noen begrunnelse for at det etter ti år ikke er kommet på plass en praktisk løsning, har det vært vanskelig å få.

\section{Ufunksjonell funksjonalitet}

I vår har det imidlertid plutselig, og uten forvarsel, dukket opp ny "funksjonalitet" $\mathrm{i}$ kurveprogrammet. Brukere som forskriver antimikrobielle legemidler må nå fylle ut et elektronisk skjema ( $f i g 1$ ) før forordningen kan effektueres. En liten gruppe såkalte superbrukere fikk tilsendt en kort brukerveiledning om dette skjemaet få dager før programvaren ble oppdatert. For øvrig er det ikke gitt noen informasjon om hva som er formålet med denne registreringen, hvilken beslutningsprosess som ligger til grunn og hvilke tilleggsdata som eventuelt skal benyttes. 


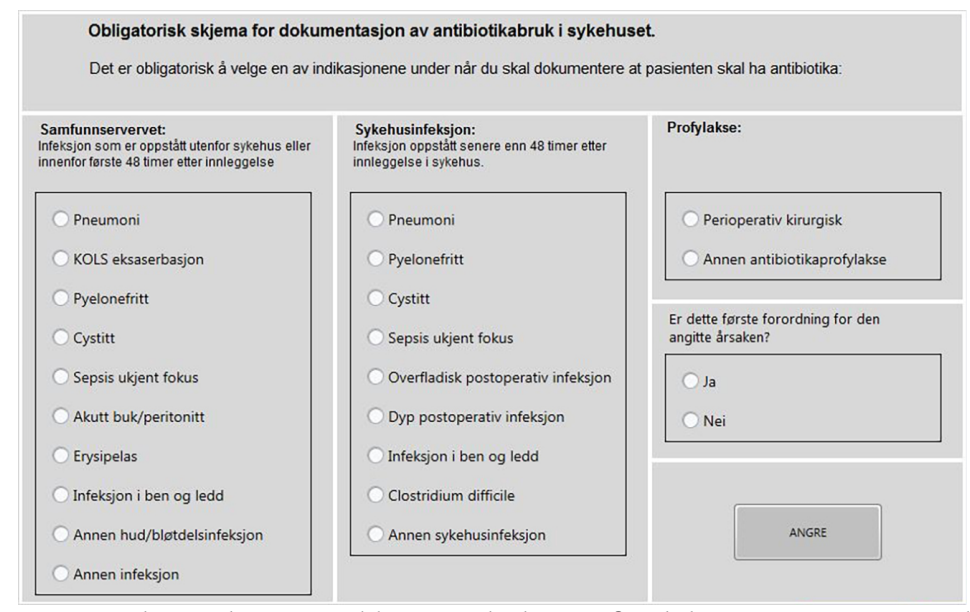

Figur 1 Skjermdump av obligatorisk skjema for dokumentasjon av antibiotikabruk i sykehuset. Gjengitt etter tillatelse fra Evry

Vi som er blitt påtvunget dette - det inkluderer også våre pasienter - vet for eksempel ingenting om hvorvidt dataene skal publiseres eller bare presenteres som et vedlegg til styremøtet i foretaket. Det fremstår imidlertid som opplagt at denne funksjonaliteten innebærer at det nå er skapt rom for å høste data fra kurvesystemet, noe som i seg selv er en overraskelse, historikken tatt i betraktning. Det innebærer også at hver enkelt lege som er pålogget kurvesystemet heretter får sin forskrivningspraksis overvåket.

I min avdeling benyttes dette kurvesystemet til intensiv- og operasjonspasienter. I intensivavdelinger har pasientene organsvikt som fellesnevner. Svært mange av dem oppfyller kriteriene for sepsis. Hos slike pasienter er behandlingen en bredt sammensatt tiltakspakke som dels tar sikte på å avhjelpe aktuell organsvikt (respiratorbehandling, dialyse, sirkulasjonsunderstøttelse), dels å forebygge utvikling av ytterligere organsvikt. Behandling av infeksjoner er ofte en del av en slik tiltakspakke. Valget av antimikrobiell strategi må tilpasses behandlingssituasjonen for øvrig. Det må tas hensyn til komorbiditet og omfang av og type organdysfunksjon, om pasienten har hatt langvarig opphold i sykehus eller kommer rett fra gaten, toksiske legemidler må unngås og interaksjoner hensyntas, dosering og behandlingsvarighet må tilpasses utvikling i inflammasjonsmarkører og kliniske manifestasjoner.

Alt dette mangler i skjemaet vi nå er pålagt å fylle ut. Det inneholder heller ingen elementer som kvalifiserer de ulike avkrysningene man må gjøre. Med en ny sepsisdefinisjon skulle man for eksempel tro det var av betydning at diagnosen var kvalitetssikret og i henhold til kriteriene (2). Med sitt begrensede «diagnoseutvalg» og sin banale utforming stimulerer skjemaet også til en feilaktig forståelse av at aktuell infeksjonsproblematikk kan ses isolert fra pasientbehandlingen for øvrig. I 2017 fremstår ikke dette som innsiktsfullt. I neste omgang utvides kanskje funksjonaliteten slik at visse antimikrobielle legemidler kun lar seg forskrive på visse vilkår.

\section{Uvillige klakører}

I forsknings-, kvalitets- og fagutviklingsarbeid er det blitt rutine at berørte parter blir tatt med i planlegging og utforming av nye prosjekter (3). Utover at dette er alminnelig folkeskikk, er det også med på å heve kvaliteten fordi prosjektledelsen ofte ikke har god nok innsikt i hvilke muligheter og begrensninger man må forholde seg til i slike prosjekter. Det mangler ikke på interesserte medarbeidere.

Ved å heve seg over slike alminnelige krav, og ved fullstendig å unnlate å informere om prosjektets formål, har prosjektledelsen i Helse $ø$ r- $\emptyset$ st i stedet gjort leger i regionens intensivavdelinger til uvillige klakører. Det er vanskelig å se at det kan bli gode data av dette. 
LITTERATUR:

1. Regjeringen. Nasjonal strategi mot Antibiotikaresistens 2015-2020. Oslo: Helse og omsorgsdepartementet, 2015.

https://www.regjeringen.no/no/dokumenter/nasjonal-strategi-mot-antibiotikaresistens-2015-2020/id2 4245981

2. Singer M, Deutschman CS, Seymour CW et al. The Third International Consensus Definitions for Sepsis and Septic Shock (Sepsis-3). JAMA 2016; 315: 801 - 10. [PubMed][CrossRef]

3. Committee on Strategies for Responsible Sharing of Clinical Trial Data, Board on Health Sciences Policy, Institute of Medicine. Sharing Clinical Trial Data: Maximizing Benefits, Minimizing Risk.

Washington D.C.: National Academies Press, 2015.

Publisert: 21. august 2017. Tidsskr Nor Legeforen. DOI: 10.4045/tidsskr.17.0491

Mottatt 1.6.2017, første revisjon innsendt 13.6.2017, godkjent 16.6.2017.

(C) Tidsskrift for Den norske legeforening 2020. Lastet ned fra tidsskriftet.no 